\title{
ANALISIS PENERAPAN AKUNTANSI LINGKUNGAN DI RUMAH SAKIT MARDI WALUYO METRO
}

\author{
Aminah \\ Noviani \\ (Universitas Bandar Lampung) \\ E-Mail: amy_ubl@ymail.com \\ E-Mail:novi_mini@yahoo.com
}

\begin{abstract}
Environmental pollution in Indonesia has reached the stage of worrying . Environment is increasingly polluted by waste from industrial activities of factories, hospitals, and hotels . This has subsequently become impulse formation Pollution Control Association (Appli) dated December 10, 2008 . Hospitals that an organization must be able to provide health insurance to the public, it is appropriate to control the waste that would have an impact on the spread of disease. Create a healthy environment should be one of the missions of organizations engaged in the field of health. So that the application of accounting and environmental management becomes an important requirement that must be done.
\end{abstract}

Keywords: accountant Environmental, hospitals

\section{Latar Belakang}

Pencemaran lingkungan di Indonesia sudah mencapai pada tahap yang menghawatirkan. Lingkungan kini semakin tercemari oleh limbah yang dihasilkan dari aktivitas industri dari pabrik, rumah sakit, dan hotel. Hal inilah yang selanjutnya menjadi dorongan pembentukan Asosiasi Pengendali Pencemaran Lingkungan (APPLI) pada tanggal 10 Desember 2008. Rumah sakit yang merupakan organisasi yang harus dapat memberikan jaminan kesehatan kepada masyarakat, sudah sepantasnya mengendalikan limbahnya yang justru akan berdampak pada penyebaran wabah penyakit. Menciptakan lingkungan yang sehat seharusnya menjadi salah satu misi organisasi yang bergerak di bidang kesehatan. Sehingga penerapan akuntansi dan manajemen lingkungan menjadi tuntutan penting yang harus dilakukan.

Penerapan Green Hospital di tahun 2013 menjadi isu yang marak diperbincangkan. Konsep rumah sakit yang berwawasan lingkungan di rumah sakit lebih diarahkan pada penggunaan air yang efektif dan efisien, penggunaan energi listrik yang efisien, serta pengelolaan limbah cair yang berwawasan lingkungan. Di sisi lain, Green Hospital harus memperhatikan adanya pengelolaan limbah padat (sampah) yang baik dan berwawasan lingkungan. Tindakan Rumah sakit sebagai upaya pelestarian lingkungan rumah sakit agar 
lebih baik, sehat dan nyaman, dapat dilakukan melalui penyediaan ruang terbuka hijau dan menjadikan rumah sakit area bebas rokok. Hal ini dapat tercipta melalui manajemen yang berwawasan lingkungan. Isu lingkungan sudah menjadi wacana dunia. Hal ini menunjukkan bahwa permasalahan yang terjadi atas pengrusakkan lingkungan sudah mencapai tingkat yang memprihatinkan sehingga harus dilakukan upaya yang teringrasi antas negara. Komite bisnis International Federation of Accountants (IFAC) adalah organisasi Akuntan dunia adalah salah satu organisasi yang banyak memberikan perhatiannya dalam permasalahan lingkungan. IFAC (2011)

\section{Tinjauan Pustaka}

\subsection{Teori Yang Mendasari}

\section{Teori Keadilan}

Di dalam perkembangan pemikiran filsafat hukum dan teori hukum, tentu tidak lepas dari konsep keadilan. Konsep keadilan tindak menjadi monopoli pemikiran satu orang ahli saja. Banyak para pakar dari berbegai didiplin ilmu memberikan jawaban apa itu keadilan. Thomas Aqunas, Aristoteles, John Rawls, R. Dowkrin, R. Nozick dan Posner sebagian nama yang memberikan jawaban tentang konsep keadilan.

\section{Teori Regulasi}

Berdasarkan teori-teori regulasi, regulasi umumnya diasumsikan akan diterima oleh industri terkait dan didesain serta dioperasikan dengan tujuan utama memperoleh keuntungan. Teori Régulasi adalah teori tentang penyelidikan terhadap faktor-faktor yang mengatur menata dan membina perubahan bentuk jangka panjang rejim-rejim ekonomi-sosial dari kerajaan kapitalisme. Hal ini merupakan suatu teori tentang teori makroekonomi, teori ini secara total berbeda dari teori regulasi mikro yang menganut desain optimal untuk mengorganisir desentralisasi utilitas publik. Teori Regulasi lahir di akhir tahun 1970-an, di mana situsai ekonomi dunia sedang dilanda resesi, setelah mengalami masa kejayaan sekitar 20-30 tahun. Pada masa tersebut, perekonomian Eropa dan Amerika tengah memasuki masa paling sulit sejak krisis hebat di Amerika tahun 1930-an.

\section{Teori Akuntansi}

Teori akuntansi adalah adalah cabang akuntansi yang terdiri dari pernyataan sistematik tentang prinsip dan metodologi yang membedakan dengan praktik. Definisi lain teori 
akuntansi merupakan suatu susunan konsep, definisi, dan dalil yang menyajikan secure sistematis gambaran fenomena akuntansi serta menjelaskan hubungan antarvariabel dalam struktur akuntansi dengan maksud untuk dapat memprediksi fenomena yang muncul. Yudiani, Anastasia Friska (2000) menganggap bahwa teori akuntansi adalah suatu sistem yang komprehensif dimana termasuk postulat dan teori yang berkaitan dengannya. Dia membagi unsure teori dalam beberapa elemen: postulat dan asumsi dasar, definisi, tujuan akuntasi, prinsip atau standar, dan prosedur atau metode-metode.

\subsection{Pengertian dan Pengendalian Pencemaran Lingkungan}

\section{Definisi Pencemaran}

Definisi pencemaran lingkungan menurut Undang-Undang Republik Indonesia nomor 23 tahun 1997 tentang Pengelolaan Lingkungan Hidup pada Pasal 1 ayat 12 adalah sebagai berikut :

Pencemaran lingkungan hidup adalah masuknya atau dimasukkannya makhluk hidup, zat, energi, dan atau komponen lainnya ke dalam lingkungan hidup oleh kegiatan manusia sehingga kualitasnya turun sampai ke tingkat tertentu yang menyebabkan lingkungan hidup tersebut tidak dapat berfungsi sebagimana peruntukkannya.

Munn (1999) dalam buku tulisannya yang berjudul A System View of Accounting for Waste menjelaskan bahwa pencemaran lingkungan sebagai bentuk atas bercampurnya senyawa asing dalam senyawa alami yang berakibat pada terbentuknya senyawa baru yang sama sekali berbeda dengan senyawa sebelumnya, atau dalam pengertian bahwa senyawa tersebut adalah komponen dari lingkungan hidup yang tercemar. Pencemaran lingkungan dapat diartikan pula sebagai penurunan kualitas kondisi lingkungan yang dimaksud yang dikarenakan gangguan atas kegiatan kegiatan oleh penyebab atau faktor rangsangan dari luar yang tidak terkontrol sesuai dengan fungsi semestinya (Gregoria, 1999).

\section{Pengolahan Air Limbah}

Salah satu limbah yang dihasilkan oleh Rumah sakit adalah limbah cair (air limbah). Oleh karena itu, pengolahan air limbah dalam bentuk instalasi pengolahan limbah (IPAL) sangat dibutuhkan oleh jenis usaha Rumah Sakit. Sadjimin,Toni (2000) mengungkakan bahwa pengolahan limbah yang dimaksudkan adalah mengurangi substansi substansi pencemar sebelum limbah tersebut dibuang kelingkungan. Sadjimin,Toni (2000) pada dasarnya pengolahan limbah meliputi 3 (tiga) tahapan proses yaitu : 
1. Pengolahan Primer

Aspek utama dalam pengolahan ini adalah pengolahan secara fisika diantaranya sedimentasi, penyaringan, dan floatasi. Pengolahan primer ini dapat mereduksi BOD atau bobot polutan sampai kira kira $35 \%$.

2. Pengolahan Sekunder

Pengolahan ini dilakukan dengan cara biologi, proses kimia maupun fisika. Proses pengolahan sekuder ini biasanya dapat mereduksi BOD sampai $90 \%$

3. Pengolahan Tersier

Pengolahan ini merupakan kelanjutan dari pengolahan sebelumnya dengan peralatan peralatan antara lain kolam, reserve osmosi, dan elektridiasis.

\subsection{Definisi Umum Akuntansi Lingkungan}

Akuntansi pada mulanya diartikan hanya sekedar sebagai prosedur pemrosesan data keuangan. Pengertian ini dapat ditemukan dalam Accounting Terminology Bulletin yang diterbitkan oleh AICPA (American Institute of Certified Public Accounting). Dalam Accounting Terminology Bulettin no.1 dinyatakan sebagai berikut: "Accounting is the art of recording, classifying and summarizing in a significant manner and in the term of money, transaction and event which are and part, at least of finantial character and interpreting the result there of"'(AICPA, 2003)

\subsection{Penelitian Terdahulu}

Dalam tulisan Purwono (2000) dinyatakan bahwa pembangunan merupakan upaya manusia mendayagunakan sumber daya alam dan lingkungan hidup dengan tujuan meningkatkan taraf hidupnya. Hal itu berarti, pembangunan akan membawa perkembangan peradaban manusia yang demikian cepat terutama bila didukung oleh kemampuan untuk menciptakan dan memanfaatkan teknologi.

Pembangunan pada hakekatnya merupakan campur tangan manusia terhadap lingkungan, oleh sebab itu dalam pembangunan selalu terjadi interaksi antara sumber daya alam, sumber daya manusia dan sumber daya binaan (Purwono, 2000). Perusahaan dianggap sebagai lembaga yang dapat memberikan banyak keuntungan bagi masyarakat sekitar dan masyarakat pada umumnya sebagai bagian dari proses pembangunan Negara (Hadisatmoko, 1998). Keberadaan perusahaan dianggap mampu menyediakan kebutuhan masyarakat untuk konsumsi maupun penyedia lapangan pekerjaan. Perusahaan di dalam lingkungan masyarakat 
memiliki sebuah legitimasi untuk bergerak leluasa melaksanakan kegiatannya, namun lama kelamaan karena posisi perusahaan menjadi amat vital dalam kehidupan masyarakat maka dampak yang ditimbulkan juga akan menjadi sangat besar (Hadisatmoko, 1998).

Munn (1999) menyatakan bahwa dampak negatif yang paling sering muncul ditemukan dalam setiap adanya penyelenggaraan operasional usaha perusahaan adalah polusi suara, limbah produksi, kesenjangan, dan lain sebagainya dan dampak semacam inilah yang dinamakan eksternal.

\section{Tahap-Tahap Perlakuan Alokasi Biaya Lingkungan}

Pencatatan pembiayaan untuk mengelola sampah-sampah yang dikeluarkan dari hasil sisa produksi suatu usaha dialokasikan dalam tahap tahap tertentu yang masing masing tahap memerlukan biaya yang dapat dipertanggungjawabkan, dan tahap tahap pencatatan itu dapat dilakukan sebelum periode akuntansi berjalan sesuai dengan proses produksi yang dilakukan perusahaan tersebut (Munn, 1999). Pengelompokkan dalam tahap analisis lingkungan sebagaimana yang ditentukan dalam Pernyataan Standar Akuntansi Keuangan (PSAK) tersebut antara lain sebagai berikut (dalam Murni, 2001):

1. Identifikasi

Pertama kali perusahaan hendak menentukan biaya untuk pengelolaan biaya penanggulangan eksternality yang mungkin terjadi dalam kegiatan operasional usahanya adalah dengan mengidentifikasi dampak dampak negatif tersebut.

2. Pengakuan

Elemen-elemen tersebut yang telah diidentifikasikan selanjutnya diakui sebagai rekening dan disebut sebagai biaya pada saat menerima manfaat dari sejumlah nilai yang telah dikeluarkan untuk pembiayaan lingkungan tersebut.

3. Pengukuran

Pengukuran nilai dan jumlah biaya yang akan dikeluarkan ini dapat dilakukan dengan mengacu pada realisasi biaya yang telah dikeluarkan pada periode sebelumnya, sehingga akan diperoleh jumlah dan nilai yang tepat sesuai kebutuhan riil setiap periode.

4. Penyajian

Penyajian biaya lingkungan ini di dalam laporan keuangan dapat dilakukan dengan nama rekening yang berbeda-beda sebab tidak ada ketentuan yang baku untuk nama rekening yang memuat alokasi pembiayaan lingkungan perusahaan tersebut. 
5. Pengungkapan

Hal ini diungkapkan oleh Jain,R.K, (1998) dalam bukunya berjudul Environmental Impact Assesment disebutkan bahwa sistem pencatatan akuntansi yang memerlukan penanganan khusus dalam hal ini adalah sistem akuntansi lingkungan yang memerlukan kamar tersendiri dalam neraca keseimbangan setiap tahunnya.

\section{Metodologi Penelitian}

\subsection{Pemilihan Sampel}

Teknik yang digunakan dalam memilih sampel adalah dengan teknik proporsional sampel, artinya pemilihan sampel dalam unit unit usaha pelayanan kesehatan tersebut dengan proporsional dari tingkat wewenang unit usaha dalam perusahaan tersebut yang berkompeten dalam masalah lingkungan. Di dalam penelitian ini sampel yang digunakan adalah unit Sanitasi lingkungan RS sebagai pelaku utama pengelolaan masalah lingkungan dan Bagian keuangan yang mengatur masalah penganggaran dan pembiayaan masalah lingkungan tersebut.

\subsection{Data}

Jenis data yang digunakan dalam penelitian ini adalah data sekunder. Dimana data sekunder adalah data yang secara tidak langsung diperoleh dari sumbernya. Data tersebut dapat berupa catatan atau literatur yang diperlukan untuk penelitian ini. Data sekunder ini diantaranya adalah profil Perusahaan sebagai perusahaan yang memiliki kegiatan utama penyediaan layanan jasa kesehatan masyarakat, data mengenai perhitungan, penilaian biaya, serta alokasi pengelolaan limbah pada laporan keuangan, data mengenai jenis- jenis limbah dan tata cara pengelolaannya disertai proses pembiayaan dalam anggaran belanja, data mengenai Instalasi Pengolahan Limbah dan Analisis Mengenai Dampak Lingkungan (AMDAL).

\subsection{Teknik Pengumpulan Data}

Dalam mengadakan penelitian, teknik pengumpulan data dilakukan sebagai berikut :

\section{a. Pengamatan (observasi)}

Pengamatan yaitu suatu teknik yang dilakukan untuk mendapatkan data dengan mengadakan pengamatan secara langsung terhadap kegiatan usaha guna memperoleh gambaran yang lebih jelas mengenai masalah yang diteliti. 
b. Dokumentasi (documentation)

Dokumentasi yaitu dengan cara mengumpulkan dokumen - dokumen atau data - data yang diperoleh dari Rumah Sakit Mardi Waluyo Metro..

c. Wawancara (interview)

Wawancara yaitu suatu teknik yang dilakukan untuk mendapatkan data dengan mengadakan tanya jawab secara langsung dengan orang - orang berwenang guna memperoleh data dan keterangan yang diperlukan secara relevan dan akurat.

d. Publikasi Lain

Publikasi lain adalah suatu teknik yang dilakukan untuk mendapatkan data - data yang berhubungan dengan penelitian ini melalui internet.

\subsection{Metode Analisis Data}

Metode analisis data yang digunakan adalah metode deskriptif komparatif yaitu peneliti mendeskripsikan hasil temuannya yang berasal dari data data yang terkumpul melalui proses observasi di subyek penelitian yang kemudian akan diperbandingkan dengan metode penerapan akuntansi lingkungan secara teori yang selama ini berkembang dikalangan akademik. Peneliti kemudian menganalisa kesesuaian metode akuntansi lingkungan yang diperbandingkan secara setahap demi tahap dalam penerapan akuntansi lingkungan tersebut pada masing masing metode dengan analisa deskripsi komparatif yang diinterpretasikan atas dasar data yang ada.

Hasil analisa perbandingan kedua metode tersebut diinterpretasikan dalam bentuk narasi argumentatif yang disajikan sebagai bentuk hasil analisis deskripsi untuk memberikan gambaran secara umum atas keunggulan dan kelemahan masing masing metode sehingga pada hasil akhir kesimpulan akan diperoleh metode akuntansi lingkungan yang baik sebagai metode alokasi biaya lingkungan yang layak untuk diterapkan pada perusahaan perusahaan.

\section{Hasil dan Pembahasan}

\subsection{Data Penelitian}

\section{Data Kualitatif Sehubungan Pengelolaan Limbah}

RS Mardi Waluyo melakukan antisipasi pencemaran lingkungan yang dilakukan oleh Unit Sanitasi Lingkungan dengan melakukan pengolahan limbah dengan menurunkan beban pencemaran sampai dengan baku mutu limbah cair yang ditetapkan yakni, dengan kadar COD yang berkisar antara 2000-4000 ppm dan menstabilkan dan mengurangi debit limbah 
yang dihasilkan oleh perusahaan. Langkah-langkah yang dilakukan yaitu: meminimalisasi pemakaian air dan mengurangi limbah-limbah medis.

\section{Data Laporan Keuangan Rumah Sakit Mardi Waluyo Metro}

RS Mardi Waluyo mencatat biaya biaya yang dikeluarkan unit tersebut dalam pengelolaan limbah. Berdasarkan pengamatan data laporan keuangan RS Mardi Waluyo Metro yakni neraca dan laporan laba rugi sebagaimana disajikan dihalaman berikut, dapat diketahui bahwa elemen-elemen aktiva, kewajiban, modal, dan beban yang berhubungan dengan limbah sudah tercantum secara eksplisit. RS Mardi Waluyo mencatat biaya unit tersebut secara tersembunyi, sehingga tidak ditampilkan secara eksplist dalam Neraca namun dimasukkan sebagai biaya administrasi dan umum.

\subsection{Analisis Deskriptif}

\section{Pengantar Analisis}

Rumah Sakit Mardi Waluyo Metro sebagai perusahaan yang bergerak dibidang pelayanan jasa kesehatan kepada masyarakat, dalam melaporkan biaya lingkungannya diakui sebagai biaya administrasi dan umum. Pengukuran biaya lingkungan tersebut dinyatakan dalam rupiah berdasar pengeluaran Unit Sanitasi Lingkungan dalam pengelolaan limbahnya. RS Mardi Waluyo dalam mengelola lingkungannya terutama masalah penanganan limbahnya dilakukan sepenuhnya oleh Unit Sanitasi Lingkungan yang merupakan bagian dari Sarana Panunjang Medis. Unit ini memiliki instalasi pengolahan limbah (IPAL) mulai beroperasi pada bulan Maret 1999 dan menjadi bagian yang penting dalam menjaga keadaan lingkungan agar tetap sesuai dengan peruntukkannya.

\section{Analisis Neraca Rumah Sakit Mardi Waluyo Metro}

Pelaporan keuangan di neraca bertujuan untuk memberikan informasi mengenai sumber daya ekonomi (aktiva), kewajiban (utang), dan modal sendiri (modal atau donasi) dari suatu entitas atau perusahaan. Neraca dengan demikian meringkaskan posisi keuangan perusahaan pada tanggal tertentu dengan menampilkan aktiva, utang dan modal serta hubungan antar item tersebut. Pengakuan (recognition) dalam konteks neraca adalah proses pencatatan dan pelaporan dalam laporan keuangan secara formal. 


\section{Laba Rugi}

Laporan laba rugi atau laporan hasil usaha (dalam sebutan RS Mardi Waluyo) merupakan laporan ringkasan dari hasil kegiatan perusahaan selama satu periode akuntansi sehingga laporan ini dipandang sebagai laporan yang paling penting dalam laporan tahunan. Laporan laba rugi RS Mardi Waluyo meliputi: Pendapatan, Biaya Langsung, Biaya Administrasi dan Umum, dan Biaya Lain lain.

Pos-pos tersebut didalam laporan laba rugi secara eksplisit tidak menunjukkan adanya elemen yang berkaitan dengan pembiayaan lingkungan. Analisis untuk penerapan akuntansi lingkungan dilakukan dengan pengamatan terhadap setiap pos elemen laba rugi dicatatan atas laporan keuangan untuk kemudian ditelusur lebih lanjut pada elemen biaya-biaya pada laporan laba rugi, biaya administrasi dan umum merupakan satu satunya elemen yang berhubungan dengan lingkungan (unit pengolahan limbah) RS.

Tabel 1

Anggaran Belanja Unit Sanitasi 2010-2011

\begin{tabular}{|l|l|l|}
\hline 1. & Pengadaan Peralatan Perkantoran & Rp. 1.285 .200 .00 \\
\hline 2. & Pengadaan Peralatan Rumah Tangga & Rp. 44.918 .900 .00 \\
\hline 3. & Biaya Listrik Instalasi & Rp. 16.468 .229 .00 \\
\hline 4. & Biaya Operasional Tambahan & Rp. 69.720 .000 .00 \\
\hline 5. & Biaya Program Lingkungan & Rp. 37.750.000.00 \\
\hline Jumlah Anggaran & Rp. 170.042.329.00 \\
\hline
\end{tabular}

\section{Analisis Tahap Perlakuan Akuntansi Lingkungan}

Akuntansi lingkungan sebagai metode untuk mengungkap dan menyajikan perlakuan biaya yang berhubungan dengan pengelolaan lingkungan memerlukan tahap tahap yang runtut dan rinci dengan tetap mengacu pada standar akuntansi maupun pernyataan akuntansi yang berlaku umum. Tahap-tahap akuntansi ini meliputi: Identifikasi, Pengakuan, Penyajian , Pengungkapan, dan Pelaporan.

\section{Analisis akhir}

Secara garis besar uraian, laba rugi, dan analisis tahapan perlakuan biaya lingkungan diRumah Sakit Mardi Waluyo Metro masih jauh dari sempurna. Penulis mengalami kesulitan dalam menginterpretasikan data sebab dengan adanya keterbatasan data dan perbedaan 
karakteristik yang mendasar dari sudut pandang akuntansi keuangan itu sendiri dalam menilai laporan keuangan RS Mardi Waluyo Metro. Sistem perlakuan di Indonesia yang menitik beratkan pada entitiy concept dan propietory concept sehingga terdapat kesulitan untuk mewujudkan penerapan akuntansi lingkungan yang prinsip dasarnya adalah society concept.

\section{RUMAH SAKIT UMUM MARDI WALUYO METRO \\ NERACA \\ Tanggal : 31 Desember 2011}

AKTIVA

\section{Aktiva Lancar}

Kas

Bank

Investasi Jangka Panjang

Piutang

Cadangan Kerugian Piutang

Persediaan

Uang Muka Biaya

Pengembangan Dana Jangka Panjang

Jumlah Aktiva Lancar
Rp. $\quad 46.863 .990 .00$

Rp. 4.260.289.321.00

Rp. $\quad 25.004 .000 .00$

Rp. 1.901.961.892.00

Rp. (47.549.058.00)

Rp. 810.583 .855 .00

Rp. $\quad 24.361 .250 .00$

Rp. $\quad 0.00$

Rp. 7.021.515.260.00

\section{Aktiva Tetap Berwujud}

Nilai Perolehan Aktiva tetap

Tanah
Gedung dan Bangunan
Emplasmen
Alat Medik
Alat Keperawatan
Mesin dan Instalasi
Perabotan
Kendaraan
Alat Kerja
Lain lain

Akumulasi Depresiasi

Gedung dan Bangunan

Rp. $\quad(799.252 .843 .00)$

Emplasemen

Rp.

Alat Medik

Rp. (1.914.183.209.00)

Alat Keperawatan

Rp.

Mesin dan Instalasi

Rp. (554.906.595.00)

Perabotan

Rp. (1.227.742.179.00)

Kendaraan

Rp. (39.538.485.00) 
Alat Kerja

Lain lain

Jumlah Aktiva Tetap Berwujud

\section{Aktiva Tetap tak Berwujud}

Biaya Pelatihan dan Pengembangan

Biaya Penelitian dabn Pengembangan

\section{Amortisasi Aktiva Tetap tak Berwujud}

Biaya Pelatihan dan Pengembangan

Biaya Penelitian dan Pengembangan

Jumlah Aktiva Tetap Tak Berwujud

Aktiva Lain lain

JUMLAH TOTAL AKTIVA

PASSIVA

\section{Kewajiban / Hutang}

Kewajiban Jangka Pendek

Barang Farmasi

Barang Gizi

Barang Pengadaan

Premi Asuransi

Pajak

Titipan Pasien

Pendapatan diterima dmuka

Kewajiban Pendek Lainnya

Jumlah Kewajiban Jangka Pendek

Kewajiban Jangka Panjang

Kewajiban Bank

Kewajiban Leasing

Kewajiban Alat Medik

Kewajiban Aktiva Tetap

Kewajiban Jangka Panjang Lainnya

Jumlah Kewajiban Jangka Panjang

\section{Jumlah Total Kewajiban}

Modal

Modal Sendiri

Modal Sumbangan

Donasi dari Perorangan

Donasi dari Badan Hukum

Donasi dari Pemerintah
Rp.

$(0.00)$

Rp. $\quad(0.00)$

Rp. 7.430.663.171.00

Rp.

0.00

Rp.

Rp.

0.00

$\begin{array}{ll}\text { Rp. } & 0.00 \\ \text { Rp. } & 0.00 \\ \text { Rp } & 0.00\end{array}$

Rp. 14.452.178.431.00

Rp. 888.766.647.00

Rp. $\quad 0.00$

Rp. $\quad 0.00$

Rp. $\quad 0.00$

Rp. $\quad 0.00$

Rp. 389.989 .023 .00

Rp. $\quad 0.00$

Rp. 482.126 .927 .00

Rp. 1.760.882.597.00

Rp. $\quad 0.00$

Rp. $\quad 0.00$

Rp. $\quad 0.00$

Rp. $\quad 0.00$

Rp. $\quad 0.00$

Rp. $\quad 0.00$

Rp. 1.760.882.597.00

Rp. 11.120.164.040.00

Rp. $\quad 288.106 .974 .00$

Rp.

0.00

$\mathrm{Rp}$.

0.00 
Donasi dari PP Muhammadiyah

Jumlah Modal

Sisa Hasil Usaha

SHU Tahun lalu

SHU Tahun Berjalan

Jumlah Sisa Hasil Usaha

Jumlah Modal
$\underline{R p}$

Rp. 11.408.271.014.00

0.00

0.00

Rp. 4.283 .024 .820 .00

Rp. 4.283.024.820.00

Rp. 12.691.295.834.00

JUMLAH TOTAL PASSIVA

Rp. 14.452.178.431.00

\section{RUMAH SAKIT UMUM MARDI WALUYO METRO \\ LAPORAN HASIL USAHA (Laporan Laba Rugi)}

\section{Pendapatan}

Tanggal : 31 Desember 2011

Pendapatan Instalasi

Rawat Jalan
Rawat Inap
Unit Gawat darurat
Intensif Care Unit
Kamar Operasi
Farmasi
Radiologi
Laboratorium
Rehab Medis
Gizi

Jumlah Pendapatan

Pengurang Pendapatan

Jumlah Pendapatan Bersih

Biaya

Biaya Langsung

Biaya Anfrah

Biaya Gizi

Biaya Jasa Medis

Biaya Pegawai

Biaya Pemakaian Peng. Brg

Biaya Pemeliharaan

Biaya Kantor dan Langganan

Biaya Belanja Gizi

Biaya Rujukan Luar
Rp. 1.108.049.578,00

Rp. 3.656.834.200,00

Rp. 1.225.628.005,00

Rp. $\quad 181.241 .750,00$

Rp. 3.452.744.045.00

Rp. 11.703.052.528,00

Rp. $\quad 883.500 .700,00$

Rp. 1.430.647.100,00

Rp. $\quad 181.478 .220,00$

Rp. $\quad 871.481 .950,00$

Rp. 24.694.658.076,00

Rp. (190.931.943,00)

Rp. 24.503.726.133,00

Rp. 11.794.679.874,00

Rp. $\quad 512.948 .530,00$

Rp. 2.472.298.002,00

Rp. 3.766.064.004,00

Rp. $\quad 673.845 .763,00$

Rp. $\quad 78.502 .311,00$

Rp. $\quad 151.722 .299,00$

Rp. $\quad 409.876 .267,00$

Rp. $\quad 435.308 .150,00$ 
Biaya Administrasi dan Umum

$\begin{array}{ll}\text { Biaya Pegawai } & \text { Rp. } 1.522 .777 .860,00 \\ \text { Biaya Pemakaian Brg. } & \text { Rp. } \quad 785.761 .538,00 \\ \text { Biaya Pemeliharaan (barang \& lingkungan) } & \text { Rp. } \quad 143.530 .729,00 \\ \text { Biaya Kantor dan Langganan } & \text { Rp. } \quad 358.472 .968,00 \\ \text { Biaya Administrasi dan Umum } & \text { Rp. } \mathbf{2 . 8 1 0 . 5 4 3 . 0 9 5 , 0 0}\end{array}$

Jumlah Biaya Administrasi dan Umum

Pendapatan dan Biaya Lain Lain

Pendapatan Lain Lain

Rp. $1.610 .671 .987,00$

Biaya Lain Lain

Rp. (1.065.016.618,00)

Jumlah Pend dan Biaya diluar Usaha

Rp. 545.655.369,00

Biaya Depresiasi

Rp. $(660.568 .387,00)$

Laba Bersih

Rp. 1. 283.024.820,00

\section{Kesimpulan dan Saran}

\subsection{Kesimpulan}

RS Mardi Waluyo Metro adalah perusahaan layanan jasa kesehatan masyarakat yang memiliki instalasi pengelolaan limbah medis dan non medis yang dikeluarkan selama proses operasional usahanya. Instalasi pengelolaan lingkungan ini dilakukan oleh Unit Sanitasi Lingkungan dibawah koordinasi langsung direksi Sarana Penunjang Medis RS. Perlakuan alokasi biaya lingkungan yang dilakukan oleh RS Mardi Waluyo dilakukan oleh bagian keuangan RS secara langsung dengan Unit Sanitasi Lingkungan yang diakui sebagai salah satu aset tetap (aktiva tetap) rumah sakit dengan konsekuensi logis biaya yang dikeluarkan oleh unit tersebut selama operasional diakui sebagai biaya operasional rumah sakit yang berpengaruh pada laporan keuangan RS Mardi Waluyo Metro.

Berdasarkan analisis neraca dan laba rugi pada laporan keuangan Rumah Sakit Mardi Waluyo Metro, dapat diketahui bahwa elemen yang terkait dengan pengelolaan lingkungan belum tersaji secara eksplisit didalam laporan keuangannya sebab elemen tersebut masih tergabung dengan elemen lainnya yang dianggap satu kategori. Hal ini juga didukung dengan tidak adanya catatan akuntansi yang menyatakan uraian dalam bentuk deskriptif yang mengungkapkan penyajian biaya pengelolaan lingkungan maupun keterangan atas aktiva yang berhubungan dengan lingkungan, seperti: Instalasi Pengolahan Limbah, Unit Sanitasi Lingkungan dan lainnya. Meskipun demikian, RS Mardi Waluyo Metro tetap mencantumkan biaya pengelolaan lingkungan dalam rencana strategis perusahaan yang disusun oleh unit 
Sanitasi Lingkungan yang kemudian dalam pelaksanaannya diakui sebagai biaya administrasi dan umum bersama sama dengan biaya-biaya lainnya yang serumpun.

\subsection{Saran}

RS Mardi Waluyo Metro sebaiknya menindak lanjuti kepeduliannya terhadap lingkungan dengan cara menyajikan berita singkat didalam laporan keuangan perusahaan, kemudian diperkuat sebagai ikhtisar kebijakan penting di bidang lingkungan didalam kebijakan akuntansinya. Pencatatan transaksi pembiayaan yang terkait dengan konservasi lingkungan sebaiknya segera dilakukan mengingat RS Mardi Waluyo sudah mencadangkan dana yang cukup banyak sebagai bukti kepeduliannya terhadap lingkungan. Langkah berikutnya yang dilakukan oleh RS Mardi Waluyo Metro adalah menyempurnakan kepedulian lingkungan tersebut dengan menyajikan "laporan lingkungan hidup" sebagai tambahan melengkapi laporan keuangan Rumah Sakit Mardi Waluyo Metro disamping memberikan catatan-catatan akuntansi mengenai kebijakan lingkungan yang telah ditempuhnya.

Model normatif yang telah diterapkan oleh RS Mardi Waluyo Metro dapat lebih disempurnakan dengan memberikan penjelasan dalam perlakuan biaya yang disisipkan dalam rekening biaya lain yang serumpun dan memberikan rincian yang jelas mengenai pembiayaan lingkungan tersebut meskipun dimasukkan dalam sub-sub rekening biaya lainnya yang serumpun. Penelitian selanjutnya dapat menggunakan Rumah Sakit di Provinsi Lampung sebagai perbandingan dengan Rumah Sakit Mardi Waluyo. Upaya ini untuk menginformasikan kepada publik bagaimana tanggung jawab sosial terhadap lingkungan dari industri Rumah Sakit di Provinsi Lampung.

\section{Daftar Pustaka}

Basuki B. Purnomo. 2000. Dasar-dasar Urologi. Jakarta : CV Sagung Seto. h. 1- 4.

Deegan, C. 2002. "The Legitimising Effect of Social and Environmental

Disclosure - A Theoritical Foundation". Accounting, Auditing \& Accountability Journal, 15(3): 282-311.

Hery, S.E., M.Si. 2009.Teori akuntansi Kencana Prenada Media Group, Jakarta

Kementerian Lingkungan Hidup Sekretariat PROPER. 2011. Program Penilaian Peringkat Kinerja Perusahaan dalam pengelolaan Lingkungan Hidup. Proper. Laporan Hasil Penilaian. 
Lindrianasari. 2004. Pemeriksaan kepatuhan terhadap pengelolaan lingkungan hidup pada perusahaan-perusahaan di Provinsi Lampung, Proceeding DepDikNas.

Patten. D. M.1992. Intra-Industry environmental disclosure in Respons toAalaska oil spill: A note on legitimacy theory. Accounting, Organizaztions adn Society 17(5): 471-475.

Sadjimin, Toni. 2000. Jurnal Epidemiologi Indonesia. Vol. 4 Edisi 1. Yogyakarta.

Whaley \& Wong's. 2003. Nursing care of infants \& children, $7^{\text {th }}$ edition. St. Louis Missouri: Mosby

Anonim, Peraturan Pemerintah nomor 27 tahun 1999 mengenai Analisis Mengenai Dampak Lingkungan. Badan Pengendalian Dampak Lingkungan, BAPEDALDA DIY, Yogyakarta, 1999

Anonim, Pemerintah Republik Indonesia, Undang Undang no. 23 tahun 1997 mengenai Pengelolaan limbah, Jakarta, 1997.

Anne, Greening accounting , www. Gulico.com/php/mail on-line tanggal 2 November 2003 pukul 24.00 GMT

Bradford. , Social Accounting; as soon as possible for accounting, Jurnal penelitian AICPA, USA, 2003

Belkoui, Ahmed, Accounting Theory, Harcott Brace Javanovich, Inc., 1981

Gregoria., A Critical View of the Social Accounting., Departement of Environmental and Energy., Environmental Enginering., Evarstone University.,Ebarstone University Press.,1999

Gray, Edmund R., dan Larry, Management: The competitive Edge, New York: Maxwell Mecmillan Publishing, 1995

Hadisatmoko, 1998, Bisnis dan Lingkungan, ditinjau dari sisi akuntansi, Artikel Majalah Media Akuntansi, Edisi V, IAI, Jakarta, 1998

Harahap, Sofyan Syafri, Teori Akuntansi, Jakarta, Raja Grafindo Persada, 1999.

Helvegia,Thomas. , Socio Accounting for Environmental , First Edition. , Grammarica press. , Journey. , Nixxon Offset. ,UK. ,2001

Hughes, Everest C. Evnvironmental a contradictive issues for accountant. ,New York, Harper colophon Books., 2002

Jain,R.K, Environmental Impact Assesment, Principle and Procedure, Scope Report,Van Nostrad Reihold Environmental. 1998

Kingston, Richard, Rubbish and System Management for International Factory, www. Encharta-ixp.gov.us/newsletter/index.php on-line tanggal 2 November 2003 pukul 22.30 GMT. 
Manuhara, Wahyu, Audit Lingkungan; Pengungkapan Isu Lingkungan dalam Laporan Keuangan, Jurnal Penelitian, Jurnal Akuntansi dan Investasi Jurusan Akuntansi FE UMY, Yogyakarta, 2000.

Murni, Sri, Akuntansi Sosial: Suatu Tinjauan Mengenai Pengakuan, Pengukuran, dan Pelaporan Eksternalities dalam Laporan Keuangan, Jurnal Penelitian, Jurnal Akuntansi \& Investasi, Jurusan Akuntansi FE UMY, Yogyakarta, 2001

Munn, A System View of Accounting for Waste, First Edition, Nixxon and Schinitteiet Universiteit Press, Bonn , 1999.

Mulyana, Deddy, Metodologi Penelitian kualitatif, Cetakan pertama, Remaja Doskarya offset, Bandung, 2001

Moeleong,Lexy, Metode Penelitian Kualitatif, Cetakan Pertama, Remaja Doskarya Offset, Bandung, 2002

Purwono, Bambang, Proses Pemanfaatan Analisis Mengenai Dampak Lingkungan dalam proyek Pembangunan, Badan Pengendalian Dampak Lingkungan ,BAPEDALDA DIY, Yogyakarta, 2002

Sudigyo, Tambah, Studi Kasus Pengolahan Limbah Cair di RS Kanker Dharmais Depkes RI Jakarta, (tidak dipublikasikan, tugas matakuliah Sanitasi lingkungan FT UGM) 2002

Sadjimin, Tony, Aspek Kesehatan dalam Analisis Mengenai Dampak Lingkungan, Tim Epidemiologi klikin dan Biostatistika FK UGM dan RSUP Dr. Sardjito Yogyakarta, (tidak dipublikasikan, makalah seminar PPLH UGM). 2000

Whaley, S., Recording and Displaying a cost for environmental system.,Int.,. J.Multiphase.,Florida.,USA.,2003

Yudiani, Anastasia Friska, Akuntansi Sosial Ekonomi: Pengukuran dan Pelaporannya, Universitas Negeri Surakarta, Skripsi, tidak dipublikasikan, 2000

Yuniati, Titi., Akuntansi Lingkungan: Pengidentifikasian, Pengukuran dan pelaporan, Universitas Negeri Surakarta, Skripsi, tidak dipublikasikan, 1998

Purwono, Akuntansi lingkungan suatu Tinjauan dalam Menghadapi Era Globalisasi dan Prospek Penerapannya di Indonesia.,Universitas Negeri Surakarta, tidak dipublikasikan, 2000

http://ilhamendra.wordpress.com/2010/10/19/teori-keadilan-john-rawls-pemahamansederhana-buku-a-theory-of-justice/

http://zetzu.blogspot.com/2010/10/pentingnya-regulasi-dalam-akuntansi.html

http://regulationschool.blogspot.com/2007/11/sejarah-teori-regulasi.html

http://getuk.wordpress.com/2006/11/26/mengulas-lagi-teori-regulasi-dan-deregulasi-2/

http://enymarie.wordpress.com/2012/03/29/paper-teori-akuntansi-bab-4/ 